\title{
POLA HIDUP KONSUMTIF REMAJA MUSLIM DI PILAR COFFEE BUKITTINGGI
}

\author{
Akdila Bulanov \\ Institut Agama Islam Negeri (LAIN) Bukittinggi \\ akdilabulanov87@gmail.com
}

\begin{tabular}{|l|l|l|}
\hline Diterima: 30 Juli 2019 & Direvisi:30 November 2019 & Diterbitkan: 30 Desember 2019 \\
\hline
\end{tabular}

\begin{abstract}
Currently among Muslim youth there has been a shift in shopping behavior to coffeshop. Muslim youths are looking for excessive entertainment because they tend to follow models of today's development. The presence of the coffeshop has an impact on the consumptive behavior of Muslim teenagers. Based on the participation observation that there is a relationship between the existence of coffeshop to consumptive behavior of Muslim teenagers. Based on the results of the analysis of Islamic economic view that the behavior of consumptive Muslim teenagers is not in accordance with the behavior in consumption in Islamic economics which refers to the three basic principles of consumption that has been outlined by Islam is kosher consumption, consumption of sacred goods and not excessive. Consumption of Muslim teenagers is included in the category of consumptive behavior.
\end{abstract}

Keywords: Consumtive behavior, Muslim youth, coffeshop.

\begin{abstract}
Abstrak
Saat ini di kalangan remaja muslim telah terjadi peralihan perilaku konsumsi. Remaja muslim mencari hiburan yang terkesan berlebihan karena mereka cenderung mengikuti model-model perkembangan zaman sekarang. Kehadiran coffeshop memberikan dampak terhadap perilaku konsumtif remaja muslim. Berdasarkan observasi partisipasi bahwa terdapat hubungan antara keberadaan kafe terhadap perilaku konsumtif remaja Muslim. Berdasarkan hasil analisis pandangan Ekonomi Islam bahwa perilaku konsumtif remaja Muslim itu tidak sesuai dengan perilaku dalam berkonsumsi dalam ekonomi Islam yang merujuk pada tiga prinsip dasar konsumsi yang telah digariskan oleh Islam yaitu konsumsi yang halal, konsumsi barang suci dan tidak berlebihan. Konsumsi yang dilakukan remaja muslim adalah masuk dalam kategori perilaku konsumtif.
\end{abstract}

Kata Kunci: Pola hidup konsumtif, remaja Muslim, kafe. 


\section{PENDAHULUAN}

Pada saat ini kemajuan perekonomian Indonesia dapat dilihat dari pesatnya perkembangan tempat berbelanja. Tempat berbelanja atau biasa disebut pasar adalah unsur yang terpenting pada aktivitasperekonomian.

Pasar menjadi penopang ekonomi, untuk kelompok strata bawah atau pun kelompok strata di atasnya. Keseluruhan aspek yang berhubungan dengan aktivitas perekonomian terdapat di pasar baik itu dari proses membuat sebuah produk, penyaluran produk, ataupun unsur mempergunakan produk tersebut. ${ }^{1}$

Pasar menjadi media bagi kelompok tertentudalam mencukupi segala yang dibutuhkan untuk hidup. Pada mulanya pasar terciptapada suatu wilayah yang luas, sehingga di wilayah tersebut individu bisa menjalankan proses interaksi untuk proses jual beli. ${ }^{2}$

Individu pada umumnya berupaya untuk mencukupi kebutuhan hidupnya, seperti kebutuhan utama (primer) yang terdiri dari sandang, pangan, papan; kebutuhan kedua (sekunder) yang terdiri dari televisi, kendaraan bermotor; kebutuhan tambahan (tersier) yang terdiri dari liburan, mobil, barang-barang mewah. Kegiatan-kegiatan yang dilakukan oleh individu dalam pemenuhan kebutuhannya pada saat ini telah berkembangan. ${ }^{3}$

Pada saat ini, kebutuhan tambahan (tersier) telah berubah dan menggeser kebutuhan utama (primer). Pola hidup yang berlebihan telah

${ }^{1}$ Chenyu Shan, Dragon Yongjun Tang, and Andrew Winton, "Do Banks Still Monitor When There Is a Market for Credit Protection?," Journal of Accounting and Economics 68, no. 2-3 (November 1, 2019): 101241, doi:10.1016/J.JACCECO.2019.101241.

2 Jau-Jia Guo and P.B. Luh, "Selecting Input Factors for Clusters of Gaussian Radial Basis Function Networks to Improve Market Clearing Price Prediction," IEEE Transactions on Power Systems 18, no. 2 (May 2003): 665-72, doi:10.1109/TPWRS.2003.811012.

3 Burkhard, Ed. Strumpel, "Economic Means for Human Needs: Social Indicators of Well-Being and Discontent." (Survey Research Center, Institute for Social Research, University of Michigan, Ann Arbor, Michigan 48106 (\$14.00 clothbound), 1976), https:/ / eric.ed.gov/?id=ED129646. merasuki masyarakat melalui media elektronik, media cetak, media sosial, dan media yang lainnya. Semua media tersebut merupakan dasar masyarakat khususnya remaja muslim dalam mengaktualisasikan diri mereka.

Pola tingkah laku merupakan sebuah cara bagi seorang individu dalam rangka bagaimana individu itu mempergunakan waktunya, apa saja yang dipikirkan individu mengenai dirinya dan mengenai lingkungan sekitar. ${ }^{4}$

Pola hidup merupakan tanda pengenal bagi seorang individu ataupun bagi sekelompok individu. Informasi dan teknologi merupakan aspek pendorong perubahan pola tingkah laku.

Arus teknologi dan informasi pada saat ini memberikan keleluasaan kepada individu khususnya remaja muslim untuk mencari petunjuk mengenai pola tingkah laku yang diinginkan oleh individu tersebut. Bukan saja lewat televisi, media cetak, tetapi juga lewat dunia digital. Individu dengan gampangnya masuk ke dunia digital dan merubah tingkah laku individu. ${ }^{5}$

Sebelum era digitalisasi, seorang indvidu mesti membeli produk luar langsung ke negara tersebut, akan tetapi pada saat ini individu dengan memanfaatkan dunia digital dipermudah dalam hal pembelian produksi luar tanpa harus pergi ke negara tersebut.

Remaja muslim juga menggunakan dunia digital untuk mengakses pola tingkah laku terkini, pola pakaian publik figur, ataupun tempat-tempat yang dijadikan remaja muslim untuk berkumpul. Pada saat ini, seseorang bukan saja menggunakan suatu barang atas dasar kebutuhan pokok saja.

Di kota Bukittinggi, remaja muslim merupakan target pasar yang menggiurkan bagi

${ }^{4}$ A. K. Mohiuddin, "Lifestyle Issues and Prevention of Recurrent UTIs," International Research in Medical and Health Science 2, no. 4 (September 4, 2019): 73-82, doi:10.36437/irmhs.2019.2.4.S.

5 Wisit Rittiboonchai, Penpicha Kriwuttisom, and Thi Minh Trang Ngo, "Factors Affecting Online Shopping Behavior Of Thai And Vietnamese Female Students," RMUTT Global Business Accounting and Finance Review 2, no. 2 (January 4, 2019), http://www.journal.rmutt.ac.th/index.php/gbafr/article/vi ew/1240. 
produsen. Melihat kepada perkembangan generasi kopi, kopi bukan lagi dilihat sebagai minuman orangtua, tetapi menjadi trend sendiri dengan menjadikannya sebagai style anak muda, yaitu update status di media sosial. Hal ini sejalan dengan penelitian yang dilakukan oleh Ardietya Kurniawan, bahwa dikalangan remaja peminum kopi, karakteristik yang menonjol adalah gaya hidup dan kehidupan sosial mereka. ${ }^{6}$ Melihat kepada perkembangan dan peluang yang ditawarkan teknologi internet melalui sosial media, tidak heran jika banyak perusahaan startup maupun perusahaan lama yang mulai melirik sosial media sebagai wadah untuk mengiklankan produk. $^{7} \quad$ Peluang inilah kemudian yang dimanfaatkan oleh coffee shop untuk mulai memasarkan kopi kepada generasi millennial.

Tabel 1.1 Konsumsi Kopi di Indonesia dari Tahun 2013-2017

\begin{tabular}{|c|c|c|c|c|c|}
\hline Tahun & 2013 & 2014 & 2015 & 2016 & 2017 \\
\hline $\begin{array}{c}\text { Konsumsi } \\
\text { kopi } \\
\text { nasional } \\
\text { (dalam 1000 } \\
\text { bungkus 60 } \\
\text { kg) }\end{array}$ & 4.042 & 4.167 & 4.333 & 4.500 & 4.600 \\
\hline \multicolumn{7}{|c|}{ Dari tabel 1.1 terlihat bagaimana }
\end{tabular}

konsumsi kopi di Indonesia meningkat dari tahun ke tahun. Berdasarkan kepada data katadata, konsumsi kopi Indonesia sepanjang periode 2016-2021 diprediksi mengalami pertumbuhan rata-rata 8,22 persen per tahun. ${ }^{8}$ Melihat perkembangan kopi di Indonesia yang semakin

6 Ardietya Kurniawan and Muh Rosyid Ridlo, "Perilaku Konsumtif Remaja Penikmat Warung Kopi," DILEMA 32, no. 1 (April 29, 2017): 9-22, https://jurnal.uns.ac.id/dilema/article/view/11232/pdf.

7 Jose Ramon Saura, Pedro Palos-Sanchez, and Antonio Grilo, "Detecting Indicators for Startup Business Success: Sentiment Analysis Using Text Data Mining," Sustainability 11, no. 3 (February 11, 2019): 917, doi:10.3390/su11030917.

${ }^{8}$ https://www.cnbcindonesia.com/news/201904101 40828-8-65742/konsumsi-kopi-global-diprediksimeningkat pesat, bahkan naik $6,3 \%{ }^{9}$ dalam kurun waktu lima tahun terakhir, maka tidak heran jika mulai banyak bermunculan gerai kopi yang menawarkan kopi Indonesia dan memadukannya dengan unsur teknologi atau seni. Berdasarkan kepada permasalahan diatas, maka

Remaja muslim senantiasa memburu pola hidup terkini. Tindakan tersebut bisa dikatakan sebagai tindakan yang konsumtif dimana di saat individu memiliki keinginan sedangkan individu tersebut belum membutuhkannya.

Pola hidup konsumtif terus mengalami perubahan sejalan dengan perubahan zaman. Pola tindakan ini memberikan keuntungan kepada produsen. Akan tetapi, apabila pola tindakan konsumtif tidak dibendung dapat menggangu kepribadian remaja muslim. Daya kreatifitas remaja muslim akan mati nantinya dikarenakan remaja muslim tersebut secara mudah dapat melampiaskan tindakan konsumtif mereka di pasar.

Hasil penelitian yang di keluarkan oleh Lembaga Perlindungan Konsumen di tahun 2013 memperlihatkan terjadinya kenaikan atas barang tersier. Pada awalnya berada di posisi $3.6 \%$ ke $19 \%$ dengan jumlah permintaan barang di tahun 2013. Subjek survey dari penelitian ini adalah masyarakat kelas menengah ke bawah yang berarti bahwa masyarakat yang berada di kelas menengah ke bawah telah mengikuti pola tingkah laku konsumtif. ${ }^{10}$

Pernyataan di atas juga dipertegas oleh Marknetter's pada tahun 2013 yang menjelaskan bahwasanya yang menggerakkan perekonomian pasar digital adalah remaja, yaitu; remaja dengan umur 17 sampai 19 tahun berada pada posisi pertama sebanyak $34 \%$, selanjutnya masyarakat yang berada pada umur 20 sampai 28 tahun sebanyak 27\%, masyarakat yang berada pada umur 28 sampai 35 tahun sebanyak 21\% dan diatas 35 tahun (18\%). Kesimpulan dari

${ }^{9}$ https:/ / food.detik.com/info-kuliner/d4229666/dibawa-oleh-belanda-hingga-jadi-kopi-kekinianmilenial

${ }^{10}$ Lembaga Perlindungan Konsumen, 2013. 
pernyataan diatas terlihat jika pasar digital dipengaruhi oleh pola tingkah laku konsumsi remaja.

Pada prisnsipnya rencana pemecahan masalah pada penelitian ini dilaksanakan dalam empat tahapan, yaitu:

1. Menguasai dan merumuskan masalah

Tahapan ini merupakan dasar dari keseluruhanmekanisme pemecahan masalah. Tahapan ini bertujuanagarpeneliti mengausai masalah pola hisup konsumtif remaja di coffeshop bukittinggi secaraobjektifserta memilahunsur yang tidak diperlukan dalam penelitian.

2. Menyusun rencana pemecahan masalah Terdapat dua bagian pada tahapan ini, yaitu:

a. Menemukan sejumlah model pemecahan yang bisa digunakan.

b. Menyusun rencana penyelesaian masalah pola hidup konsumtif remaja muslim di coffeshop bukittinggi.

3. Pada penelitian, pemecahan masalah bukan satu akan tetapi terdapat berbagai macam cara. Setiap cara pemecahan masalahpunyacirinya masing-masing. Penelitimemilih satu cara dari banyaknya pilihan dalam pemecahan masalah Setelah peneliti memilih satu cara, maka penelitimenyusun rencana outline pemecahan masalah dan membatasi masalah padapotongan yang sederhana.

4. Menyusun dan memilihcara untuk mendapatkanmodel penyelesaian

Tahapan inibeirsi mengenai perbaikan dari outlinemengenai pola hidup konsumtif remaja di coffeshop bukittinggi.

5. Memverifikasi dan menyajikan temuan dari pemecahan masalah.

Pada tahapan ini, semua temuan penelitian diperiksa seberapa validtemuan penelitianjika menggunakan tahapan yang ditentukansudah menjawab tujuan penelitian. Disamping itu juga untuk mendeskripsikan bagaimana kegunaan dari tahapan yang dipilih.

\section{METODE PENELITIAN}

Penelitian ini menggunakan pendekatan kualitatif deskriptif. Teknik pengumpulan dan analisa data melalui observasi, dokumentasi serta wawancara dengan maksud menggambarkan, merangkum suatu kenyataan empiris yang tengah terjadi. Dalam penelitian ini menjelaskan pola hidup konsumtif remaja muslim di kota Bukittinggi.

Penelitian ini dilaksanakan di Kota Bukittinggi. Pada penelitian ini, data didapatkan dengan cara observasi, wawancara dan dokumentasi. Proses analisa data dikerjakan semenjak awal, dimulai dengan merubah data yang diperoleh di lapangan menjadi kata-kata yang kemudian kata-kata tersebut di analisa, agar mendapatkan informasi mengenai fenomena atau kejadian.

Penelitian ini melakukan penyajian data dengan cara memaparkan data yang sudah melalui tahap penyederhanaan, setelah data di sajikan kemudian dapat ditarik kesimpulan. Berdasarkan hasil reduksi data, data kemudian ditampilkan dengan kalimat deskripsi, didukung oleh fakta dari dokumen.

\section{TEMUAN PENELITIAN}

Remaja muslim mengetahui bahwasanyasupaya mereka itu tidak tertinggal dari fenomena-fenomena terbaru dibutuhkan modal yang tidak sedikit. Hasrat remaja muslim tidak lagi terbendunguntuk menggunakan sejumlah uang dalam upaya mengikuti fenomena-fenomena tersebut. Berbagai fenomena yang lagi viral senantiasa mengalami perubahan pada setiap tahunnya. akibat dari globalisasi.

Remaja muslim berkeyakinan apabila mereka mengikuti berbagai fenomena yang viral akan berdampak kepada proses interaksi mereka dengan masyarakat di sekitar mereka. Dalam berinteraksi, terutama dalam memilih berkumpul, remaja muslim lebih selektif dalam menetukan lokasi ngumpul karena mereka berkeinginan 
untuk mengikutifenomena terbaru bukan karena kebutuhan.

Pola hidup konsumtif remaja muslim secara nyata tidak hanya terjadi pada remaja dengan status ekonomi menengah ke atas namun juga terjadi pada remaja muslim dengan status ekonomi rendah. Penulis melakukan observasi dan wawancara terhadap 3 orang remaja muslim pada 7 Desember 2019 di Pilar Coffee Bukittinggi. Pendapat remaja muslim yang pertama bernama Dody H mengatakan:

"Suasana nyaman tempatnya adem ga bikin bosan."

Remaja muslim bernama Bim
menuturkan:

"Salah satu café terbaik yang pernah saya kunjungi adalah pilar café ini. Suasananya tenang dan kopinya enak."

Pendapat di atas diperkuat oleh remaja muslim lainnya bernama Rahmat yang mengatakan:

"Pilar café enak buat santuyy."

Berdasarkan wawancara di atas dapat dianalisis bahwa remaja muslim tersebut lebih mengutamakan tampilan ketika memilih lokasi untuk berkumpul.

Bagi anak remaja muslim, apapun status sosial dan ekonomi yang disandangnya baik berstatus rendah ataupun menengah ke atas, merasa bahwa tampilan luarmemiliki peran yang sangat mempengaruhipadainteraksi sosial, utama sekalipada interaksi dengan lawan jenis. Kepercayan dirinya terasa semakin tumbuh sehingga pergaulan individu tersebut tidak terhambat.

Sejalan dengan perubahanarus globalisasi yang terjadi di zaman menciptakan pergeseran nilai dan norma dalam kelompok tertentu. Disamping itu juga, kemajuan yang dialami olehpusat perbelanjaan saat ini juga menciptakan perubahan cara berpikir di kelompok tertentu.

Berbagai perubahan yang terasa sangat drastic membuat penjual barang dan jasa menyusun strategi tertentu dalam upaya memenuhi hasrat pembeli. Adapun strategi yang dipilih oleh para penjual barang dan jasa untuk memikat pembeli adalah dengan memasarkan barang dan jasa dengan ramah, menyediakan tempat yang nyaman bagi pembeli, serta tambahan ornamen pada tempat belanja.

Pembeli yang cerdas senantiasa memperhatikan beberapa unsur yang berhubungan erat dengan barang dan jasa yang dijajakan yaitu unsur nilai suatu barang dan jasa, berbagai kemudahan yang akan diterima oleh si pembeli, tempat belanja yang mudah dijangkau, kerahaman dalam melayani si pembeli serta banyak faktor pendukung lainnya yang dijadikan pertimbangan bagi pembeli sebelum menentukan pilihannya. Pada saat sekarang ini, individu mengambil keputusan untuk membeli suatu barang dan jasa tidak atas dasar rasa butuh melainkan karena rasa keinginan dan kesenangan pribadi individu tersebut, yangpada akhirnya melahirkan sosok individu yang konsumtif.

Konsumerisme menunjukan identitas diri, konsumerisme merupakan aktivitas sosial untuk diri sendiri (memutuskan membeli atau tidak) atau sebagai kompetisi pada teman anggota masyarakat (sebagai simbol status, gengsi dan image manusia modern tidak ketinggalan zaman).

Para remaja muslim telah mengenal gaya hidup modern, hal ini dapat dilihat dari cara mereka membeli barang-barang yang sedang di gandrungidengan hargayang mahal.

Seiring dengan perkembangan kota-kota besar, telah terjadi perubahan di berbagai sektor, termasuk industri dan produksi. Pergesaran pola perbelanjaan zaman ini tidak bias dipisahkan dari aspek melonjaknya angka penduduk Republik Indonesia, serta perubahan pada angka penghasilan kelompok tertentu yang memberikan dampak terhadap kondisi kehidupan masyarakat secara luas. Kondisi di atas merubah pola tindakan individu dalam mengkonsumsi suatu barang dan jasa, dimana dengan adanya perkembangan kondisi kehidupan individu maka desakan akan kondisi lokasi perbelanjaan yang 
aman dan nyaman untuk memenuhi hasrat belanjan individu semakin diperlukan.

Perubahan sosial budaya adalah sebuah gejala berubahnya struktur sosial dan pola budaya dalam suatu masyarakat. Perubahan sosial budaya merupakan gejala umum yang terjadi sepanjang masa dalam setiap masyarakat. Perubahan itu terjadi sesuai dengan hakikat dan sifat dasar manusia yang selalu ingin mengadakan perubahan.

Menurut Talcott Parsons tentang perubahan sosial menjelaskan bahwa perubahan budaya terjadi karena beberapa faktor. ${ }^{11}$ Di antaranya komunikasi; cara dan pola pikir masyarakat; faktor internal lain seperti perubahan jumlah penduduk, penemuan baru, terjadinya konflik atau revolusi; dan faktor eksternal seperti bencana alam dan perubahan iklim, peperangan, dan pengaruh kebudayaan masyarakat lain. Ada pula beberapa faktor yang menghambat terjadinya perubahan, misalnya kurang intensifnya hubungan komunikasi dengan masyarakat lain; perkembangan IPTEK yang lambat; sifat masyarakat yang sangat tradisional; ada kepentingan-kepentingan yang tertanam dengan kuat dalam masyarakat; prasangka negatif terhadap hal-hal yang baru; rasa takut jika terjadi kegoyahan pada masyarakat bila terjadi perubahan; hambatan ideologis; dan pengaruh adat atau kebiasaan.

Dan perubahan sosial budaya di masyarakat bisa terjadi akibat adanya faktor yang berasal dari masyarakat itu sendiri dan faktor yang berasal dari luar masyarakat itu sendiri.

Pola hidup yang konsumtif adalahsebuah kegiatan yang marak menjangkiti individu pada saat ini. Pola hidup pada saat ini telah tumbuh secara signifikanke arah yang tidak baik, contohnya tata caraberpenampilan dan penggunaan sebuah barang dan jasayang kelewat batasdan pada akhirnya melahirkan pola hidup konsumtif. Pola hidup konsumtif ini senantiasa

\footnotetext{
11Soekanto, Soerjono. Sosiologi Suatu Pengantar. (Jakarta: Raja Grafindo Persada, 1990), 34
}

merayu pembeli untuk mengeruk habis isi kantongnya untuk melampiaskan hasrat dan keinginan individu tersebut.

Pola hidup konsumtif ini juga dipengaruhioleh perkembangan media sosial yang senantiasa menciptakan tampilan-tampilan yang menggoda hasrat pembeli untuk menyalurkan pola hidup konsumtifnya. Kondisi di zaman inidengan segenap bentuk perkembangan ilmu dan teknologi, mengakibatkan hilangnya ruang di kehidupan individu untuk merespon dengan bijak mengenai kondisi di sekitarnya. Keberadaan media sosial memungkinkan individu tersesat ke ruang maya yang diciptakannya sendiri.

Pola hidup konsumtif senantiasa terjadi di tataranlokasi perbelanjaan, salah satunya diPilar Coffee. Pilar Coffe adalah salah satu coffee shop terbaik di Bukittinggi yang menawarkan tampilan yang unik berhias interior yang menariksertawarna warni dindingyang menyilaukanmata individu yang berkunjung.

Pilar Coffee berada tepat di tengah-tengah jantung kota Bukittinggi yaitu di Jalan Prof Hazairin No 63 Kelurahan Bukik Cangang Kayu Ramang, Guguk Panjang, Bukit Cangang Kayu Ramang, Guguk Panjang, Kota Bukittinggi, Sumatra Barat.

Mengunjungi Pilar Coffe yang menyuguhkan pesona yang nyaman, pastinya bias memuaskan hasrat remaja muslim, disamping memang Kota Bukittinggi merupakan kota wisata yang sangat ikonik. Pesona lingkungan yang di tonjolkan Kota Bukittinggi, menjadikan pemilik Pilar Coffe menggunakan potensi tersebut untuk membujukremaja muslim agar dating mengunjungi Pilar Coffee.

Remaja muslim yang gemar fotografi, selfie, pemburu wifie gratis, dan membuat flog, akan terpuaskan dengan pesonayang indah dan nyaman Pilar Coffee. Pilar Coffe melayani pembeli dari berbagai kalangan, bukan hanyadari kelompok menengah ke atas saja, tapi juga kelompok menengah ke bawah. Pilihan kopi yang akan disajikanberbagai macam yang bias disesuaikan dengan harga yang ditawarkan. 
Keberadaan lokasi Pilar Coffee yang mudah untuk dikunjungimemberikan nilai plus yang kepada remaja muslim yang akan dating berkunjung, disamping juga rasa nyaman yang ditawarkan, membuat remaja muslimmau berlama-lama di Pilar Coffe. Pilar Coffe menerima kunjungan dari para pengunjung setiap hari dari pukul 10.00 sampai pukul 22.00 WIB.

Remaja muslim bias terpuaskan dengan hadirnya Pilar Coffee. Pilar Coffee juga mempromosikanprinsip coffee shop syariah, dimana Pilar Coffe tidak menjual minuman beralkohol, disamping itu pengunjung dilarang mengkonsumsi minuman beralkohol di Pilar Coffee.

Hasil observasi peneliti yang dilakukan di malam minggu, Pilar Coffelebih banyak dikunjungi oleh remaja musli. Selain berkunjung untuk nongkrong, ditemukan juga remaja muslim yang mengunjungi Pilar Coffee untuk mengerjakan tugas kuliahnya di sana sembari menikmati secangkir kopi yang nikmat.

Peneliti juga menemukan remaja muslim yang langsung jatuh hati sewaktu pertama kali datang dan berkunjung ke Pilar Coffee. Kenyamanan yang disugukan olehPilar Coffeemembuat remaja muslim senang dan betah, serta merelakan waktunya untuk dihabiskan di Pilar Coffee. Remaja muslim merasa nyaman di Pilar Coffe, karena Pilar Coffeememberikan pelayanan yang sangat baik sehingga remaja muslim bisa santaisembari minum kopi dengan teman-temannya.

Keberadaan Pilar Coffee menjadiwadah sempurna bagi individu dengan segenap kenyamanan yang ditawarkan. Di samping itu, keberadaan Pilar Coffeejuga dijadikan alat bagi kelompok tertentu demi menemukan kesenangan, sehingga hasrat konsumtif kelompok tersebut terpuaskan.

Kelompokdengan strata ekonomi yang beragam di daerah yang relative maju, keberadaan Pilar Coffee sudah seperti tempat tinggal kedua bagi remaja muslim. Kelompok tersebut ingin mempertontonkan kepada masyarakat luas bahwasanya kelompok tersebut bisa eksis mengiringi perkembangan terbaru. Walaupun setiap waktu perkembangan terbaru tersebut terus muncul, akan tetapi hasrat untuk pola hidup konsumtif tersebut tidak pernah pudar..

Remaja muslim ialah bagian dari kelompok muslim yang akan menceburkan diri kefase dewasa, remaja muslim semestinya memanfaatkan setiap sendi kehidupannya melalui ilmu dan pengetahuan, hard dan softskill, kreatifitas, dan mememuhi aktivitasnya dengan segala bentuk aktivitas yang bermanfaat yang pada akhirnya memberikan kontribusi untuk kehidupan mendatang.

Pada saat sekarang ini, lingkungan social memberikan warna tersendiri dalam pola hidup remaja muslim, dan tidak jarang hal ini menimbulkan pergeseran nilai dan norma terutama sekali dalam pola hidup konsumsi.

Remaja muslim seakan berpacu menonjolkan setaip aspek yang dikonsumsi mereka. Pergeseran pola hidup konsumsi ini tanpa memandang jenis kelamin, laki-laki dan perempuan mempunyaikesempatan yang sama untuk terjerumus dalam pola hidup konsumtif.

Remaja muslim lebih memilih untuk membelanjakan isi kantongnya demi mengunjungi Pilar Coffee, demi hasrat dan kesenangan semu. Pola hidup konsumtif ini dilakukan ini sesuai dengan apa yang diutarakan oleh pengunjung remaja muslim bernama Rahmat, yang menyatakan:

"saya memilih Pilar Café karna, fenomena
coffee shop ini lagi trend dan digandrungi
oleh teman-teman saya. Jika saya
nongkrong juga di sini, saya akan selevel
dengan mereka."

Remaja muslim lebih memilih nongkrong ke Pilar Coffee daripada membelanjakan uang mereka untuk keperluan mereka dalam menuntut ilmu. Adapun kriteria perilaku konsumtif adalah:

1. Senantiasa membelanjakan uang mereka untuk barang tidak atas dasar nilai guna dari barang tersebut. 
1. Senantiasa membelanjakan uang mereka untuk barang model terbaru.

2. Keinginan yang kurang untuk menyimpan uang mereka.

3. Intensitas untuk membelanjakan uang mereka yang tinggi, minimal berbelanja dua kali sebulan.

4. Dalam satu kali belanja bias membelanjakan uangnya minimal Rp100,000,-

5. Lebih banyak uang yang dibelanjakan dibandingkan dengan uang yang didapatkan.

Berdasarkan hasil analisa wawancara yang dilakukan oleh peneliti ditemukan bahwasanya remaja muslim di Bukittinggi banyak mengunjungi Pilar Coffe. Ini dibuktikan dengan wawancara dengan Dosen, menurut beliau mahasiswa di kampus tempat dia mengajar tidak ada yang belum pernah pergi ke Pilar Coffee, remaja muslim senantiasa meluangkan waktunya untuk mengunjungi berbagai jenis coffee shop.

Berdasarkan observasi partisipasi di Pilar Coffee terlihat bahwa remaja muslim muslim merasa malu dan gengsi jika belum pernah mengunjungi Pilar Coffee, karena mereka akan dikucilkan temanya. Remaja muslim banyak terjebak dalam kehidupan konsumtif, remaja muslim di Bukittinggi rata-rata pengeluaran yang dikeluarkan selama satu bulan dari uang sakunya yaitu untuk nongkrong, untuk kepentingan konsumtif yang bersifat kesenangan.

Salah satu karakteristik masyarakat postmodern yang disampaikan oleh sosiolog bernama Anthony Giddens yaitu seringnya remaja muslim terperangkap ke dalam pusaran gaya hidup dan citra diri yaitu ketika budaya konsumtif menjadi cara dan media bagi remaja muslim untuk mengekspresikan diri, ketika remaja muslim tumbuh dan berkembang menjadi kelompok masyarakat pesolek yang lebih mementingkan tampilan lebih utama dibandingkan nilai kegunaannya.

Dari hasil observasi di Bukittinggi banyak pengeluaran yang bersifat kesenangan saja, banyak remaja muslim yang melakukan kegiatan konsumtif. Berdasarkan hasil observasi peneliti di Pilar Coffee ditemukan bahwasanya remaja muslim selalu berusaha untuk mengikuti dan memiliki jenis coffee yang sedang trend.

Remaja muslim selalu berusaha untuk mengikuti kemajuan coffee shop dengan mengunjungi Pilar Coffeyang sedang trend tanpa memikirkan harga barang mahal atau berfikir barang tersebut dibutuhkan apa tidak yang penting tidak ketinggalan zaman oleh temantemanya.

Hasil analisa data yang didapat peneliti di lapangan terungkap bahwa remaja muslim di kampusnya tersebut terkenal dengan sifat gengsi dan jika tidak pernah merasakan jenis kopi yang sedang trend maka akan dianggap kudet atau kurang update. Remaja muslim senantiasa penasaran dengan jenis kopi yang lagi viral, mereka tidak berfikir panjang apakah barang tersebut dibutuhkan apa tidak yang jelas mereka membeli sesuai dengan keinginana mereka.

Gaya hidup seseorang dapat dilihat dari perilaku yang dilakukan individu seperti kegiatan untuk mendapatkan barang dan jasa. Faktorfaktor yang mempengaruhi gaya hidup seseorang ada 2 faktor yaitu faktor internal dan faktor eksternal. Faktor internal yaitu sikap, pengalaman dan pengamatan, kepribadian, konsep diri, motif dan persepsi sedangkan faktor eksternal yaitu kelompok referensi, keluarga, kelas sosial dan kebudayaan.

Konsep diri merupakan pandangan, penilaian, dan perasaan individu terhadap diri sendiri baik secara fisik, psikis, sosial maupun moral. Setiap individu mempunyai konsep diri positif dan konsep diri negatif. Konsep diri positif adalah individu yang memandang dirinya menyenangkan terhadap dirinya, sedangkan kosep diri negatif adalah individu yang melihat dirinya gagal, tidak mampu dan memepunyai pandangan buruk terhadap dirinya. Konsep diri merupakan salah satu faktor perilaku konsumtif yang berarti konsep diri mempengaruhi perilaku konsumtif. Individu yang memiliki konsep diri yang positif tidak akan mudah dipengaruhi untuk melakukan 
konsumerisme sebaliknya apabila individu memiliki konsep diri negatif akan mudah melakukan konsumerisme.

Memperhatikan faktanya di lapangan, sebagian besar remaja muslim hampir setiap hari menghabiskan waktunya untuk nongkrong di Pilar Coffee bersama teman-temannya. Akan tetapi, remaja muslim sangat jaranguntuk memanfaatkan waktunya untuk membaca dan membeli buku pengetahuan. Remaja muslim semestinya sebagai motor penggerak perubahan ke arah yang lebih baik dalam menerapkan pola hidup, sebabremaja muslim telah menerima berbagai pengetahuan akanpola hidup konsumtif.

Remaja muslim menyadari sepenuhnya jikalau dahulunya sebelum maraknya coffeeshop, remaja muslim belum sekalipun membelanjakan uangnya lebih dari Rp 100,000 dalam sehari. Sesudah kemunculan dan menjamurnya coffeeshop meningkatkan kuantitas uang yang mereka belanjakan minimal Rp 100,000 untuk nongkrong di coffeeshop bersama teman-temannya.

Dengan berbagai alibi, seperti ruangan coffeeshop yang nyaman, membuat remaja muslim betah berlama-lama dan menghabiskan waktunya di sana. Pola hidup dalam berkonsumsi remaja pun pada akhirnya mengalami pergeseranke pola hidup konsumtif.

Pola hidup konsumtif adalah pola tindakan indvidu dalam mengkonsumsi barang tanpa adanya dasar pemikiran yang logis sehingga mengkonsumsi barang tanpa batas. Dengan memperhatikan aturan-aturan dalam islam perilaku konsumtif tersebut harus dihindari kerena Allah SWT Swt $\}$ berfirman dalam terjemahan Q.S. Al-Isrā',17: 26-27:

$$
\text { Surat Al Isra' ayat } 26 \text { sampai }
$$

27 menjelaskan bahwa di dalam Islam kegiatan konsumsi itu ada batasan yakni seorang muslim dilarang untuk berlaku boros atau menghamburhamburkan harta secara berlebihan. Jelaslah tidak diragukan lagi bahwa Alquran adalah sumber utama dan sunah merupakan sumber kedua yang merupakan pelengkap bagi Alquran.
Manusia memiliki kebutuhan yang beragam jenisnya baik yang bersifat fisik maupun rohani. Islam melihat aktivitas ekonomi adalah salah satu cara untuk menumpuk dan meningkatkan pahala menuju falah (kebahagian dunia dan akhirat).

Agama Islam tidak pernah melarang seorang individu untuk memperoleh apa yang dibutuhkannya selama tidak melanggar aturan agama dan tidak secara berlebihan. Kegiatan memakai barang adalah kegiatan akan terus berhubungan dengan interaksi individu untuk mencukupi apa individu butuhkan.

Surat Al A'raf ayat 31 sudah terlebih dahulu memberitakan kepada umat muslim untuk senantiasa memanfaatkan barang atau jasa berdasarkan kebutuhan jangan berlebihan yang diistilahkan sebagai tindakan Isräf yaitu melewati garis wajar.

Berdasarkan penjelasan ayat tersebut, dapat dipahami bahwasanya Allah SWT sudah memberikan peringatan ke umat-Nya untuk meninggalkan pola hidup konsumtif. Pola hidup konsumtif tergolong kepadaindividu tak beriman. Syariat dalam agama islam suidah secara jelas mengajak umatnya untuk menggunakan pola hidup konsumsi yang sesuai dengan kebutuhan hidup.

Agama Islam sudah memberikan rambu dalam mengkonsumsi sebuah barang dan jasa. Pola hidup isrāf tidak dibolehkan dalam islam meskipun barang atau jasa yang di konsumsiitu halal dan baik. Akan tetapi, Allah SWTselalu mengajakumat-Nyasenantiasa mensyukuridan memanfaatkan semua nikmat yang telah di bagi, tanpa berlebihan.

Menurut pandangan ekonomi Islam, tujuan konsumsi adalah memaksimalkan maslahah. Tiga prinsip dasar konsumsi yang digariskan oleh Islam, yaitu konsumsi yang halal, konsumsi barang suci dan bersih, dan tidak berlebihan. Tidak berlebihan di sini ialah menerapkan asas sederhana: asas sederhana pada konsumsi maksudnya yaitu individu mesti makan dan minum secara wajar. 
Dalam surat Al A'raf ayat 31 dijelaskan bahwasanya kesederhanaan bukan hanya untuk makan-makanan yang berlebihan namun juga berlaku pada perbelanjaan. Berlebih-lebihan atau perilaku sifat yang tidak disukai Allah SWT, meskipun barang yang dibelanjakan adalah halal namun dilarang untuk berlaku kikir maupun boros.

Surat Al Furqan ayat 67 menjelaskan bahwa Allah SWT melarang apabila berbelanja tidak boleh berlebihan (boros) dan tidak kikir. Hendaknya berlaku sesuai dengan kebutuhan atau di tengah-tengah. Islam membolehkan seorang muslim untuk menikmati berbagai karunia kehidupan dunia dalam batas kewajaran yang menjurus kepada pemborosan dan kemewahan.

Pengarahan perbelanjaan dan konsumsi adalah jalan hidup Islam yang terpuji, baik dalam makanan, minuman, pakaian, tempat tinggal, maupun dalam aspek apa saja dari berbagai aspek kehidupan.

Alquran melarang perbuatan yang melampaui batas (berlebih-lebihan) dalam berbelanja dan menikmati rizki yang baik. Allah SWT telah menyerukan kepada umat manusia bahwa dia tidak menyukai orang-orang yang berlebih-lebihan.

Dalam Islam, kekayaan pada dasarnya merupakan salah satu unsur pemenuhan kebutuhan hidup manusia yang ditentukan oleh konsep maslahah. Konsep maslahab ini terkait erat dengan kerangka maqashid al-sha'riah (tujuan syariah), yakni untuk mencapai kesuksesan hidup di dunia dan akhirat (falah) serta kesejahteraan umat manusia (maslahat al-ibad). Oleh karenanya, semua barang dan jasa yang memiliki maslahah dapat digolongkan sebagai kebutuhan manusia. ${ }^{12}$

Imam Shatibi selanjutnya membedakan maslahah menjadi tiga jenis, yaitu esensial (daruriyyah), pelengkap (bajiyyah), dan

12 Ismail Ismail, "Eksistensi Ushul Fiqh Dalam Tafsir Realitas Sosial Dan Peranan Pesantren Dalam Menjaga Dan Mengembangkannya," Alburriyah: Jurnal Hukum Islam (Alhurriyah Journal Of Islamic Law) 4, no. 1 (June 30, 2019): 1, doi:10.30983/alhurriyah.v4i1.1264. penyempurnaan

(embellishments/tabsiniyyah).

Daruriyyah, komponen pertama, merupakan halhal yang wajib adanya dan pokok kebutuhan hidup manusia. ${ }^{13}$ Mengabaikan hal-hal yang termasuk ke dalam kelompok ini akan berujung kekacauan.

Dalam pengertian ini, hal-hal yang bersifat dharury bagi manusia berpangkal pada pemeliharaan lima hal pokok dalam maqasid alshari'ah, yakni pemeliharaan jiwa, agama, akal, harta kekayaan, dan anak atau keturunan. Hajizyah adalah sesuatu yang melengkapi hal-hal esensial (daruriyyah) yang jika di abaikan akan memberikan kesukaran atau kesulitan dalam kehidupan manusia. ${ }^{14}$ Contoh dalam bidang ekonomi, adalah penggunaan uang untuk mempermudah tukar menukar barang dan transaksi lainnya, serta kebolehan melaksanakan transaksi dengan akad mudharabah, musaqat, muzara'ah, dan ba'i salam.

Terakhir tahsiniyyah merupakan hal-hal yang umumnya mengandung nilai estetika yang baik sehingga dapat meningkatkan dan menyempurnakan kualitas hidup manusia. Tanpa keberadaannya, kehidupan manusia masih tetap bisa berjalan dengan normal akan tetapi belum sempurna. Hal yang bersifat tahsiniyyah biasanya berpangkal dari tradisi yang baik dan segala tujuan peri kehidupan manusia menurut jalan yang paling baik. Contohnya penggunaan teknologi ATM (Anjungan Tunai Mandiri) untuk transaksi perbankan serta pengembangan kualitas produksi dan hasil pekerjaan. Dari tiga kebutuhan pokok tersebut, pemeliharaan dharury merupakan prioritas. Sementara bijiyyi boleh ditinggalkan apabila memeliharanya dapat merusak hukum dharury dan bijizyi.

13 Wahyu Abdul Jafar, "Eksistensi Wakaf Tunai Dalam Tinjauan Maslahah Mursalah," Alhurriyah: Jurnal Hukum Islam (Alburriyah Journal Of Islamic Law) 4, no. 1 (June 30, 2019): 21, doi:10.30983/alhurriyah.v4i1.817.

14 Mohammad Hipni, "The Study of Maqashidi Sharia Toward Maduresse Traditional Inheritance by Using System Approach," AL-IHKAM: Jurnal Hukum \& Pranata Sosial 14, no. 1 (June 30, 2019): 50, doi:10.19105/alihkam.v14i1.2159. 
Berdasarkan penjelasan-penjelasan di atas dapat diambil kesimpulan bahwa kegiatan konsumsi yang dilakukan oleh remaja muslim muslim terhadap perilaku konsumtif dengan berbelanja di coffe shop dinilai termasuk dalam pola hidup yang berlebihan. Sedangkan fakta yang terjadi di lapangan sesuai dengan data yang diperoleh rata-rata penghasilan/pemberian sebesar $\mathrm{Rp}<1.000 .000$ s.d. Rp 1.000 .000 yang lebih mendominasi, sedang jumlah kunjungan 1 s.d. 5 kali, serta pengeluaran setiap kali kunjungan sebesar $\pm \mathrm{Rp} 100,000$ s.d. Rp 200,000. Berdasarkan data tersebutlah penulis dapat menyimpulkan bahwa kegiatan konsumsi remaja muslim termasuk dalam perilaku konsumtif.

Berbelanja di coffeshop jika dilihat dari tiga konsep maslahah coffeshop hanya sebagai penyempurna (tabsiniyyab).

\section{KESIMPULAN}

Pada saat sekarang ini, lingkungan sosial memberikan warna tersendiri dalam pola hidup remaja muslim, dan tidak jarang hal ini menimbulkan pergeseran nilai dan norma terutama sekali dalam pola hidup konsumsi.

Remaja muslim berpacu menonjolkan setaip aspek yang dikonsumsi mereka. Pergeseran pola hidup konsumsi ini tanpa memandang jenis kelamin, laki-laki dan perempuan mempunyai kesempatan yang sama untuk terjerumus dalam pola hidup konsumtif.

Remaja muslim semestinya memanfaatkan setiap sendi kehidupannya melalui ilmu dan pengetahuan, hard dan softskill, kreatifitas, dan mememuhi aktivitasnya dengan segala bentuk aktivitas yang bermanfaat yang pada akhirnya memberikan kontribusi untuk kehidupan mendatang.

\section{DAFTAR KEPUSTAKAAN}

Hipni, Mohammad. "The Study of Maqashidi Sharia Toward Maduresse Traditional Inheritance by Using System Approach." AL-IHKAM: Jurnal Hukum \& Pranata
Sosial 14, no. 1 (June 30, 2019): 50. doi:10.19105/al-ihkam.v14i1.2159.

Ismail, Ismail. "Eksistensi Ushul Fiqh Dalam Tafsir Realitas Sosial Dan Peranan Pesantren Dalam Menjaga Dan Mengembangkannya." Alburriyah: jurnal bukum islam (alburriyah journal of islamic law) 4, no. 1 (June 30, 2019): 1. doi:10.30983/alhurriyah.v4i1.1264.

Jafar, Wahyu Abdul. "Eksistensi Wakaf Tunai Dalam Tinjauan Maslahah Mursalah." Alburriyah: Jurnal Hukum Islam (Alburriyah Journal of Islamic Law) 4, no. 1 (June 30, 2019):

21. doi:10.30983/alhurriyah.v4i1.817.

Jau-Jia Guo, and P.B. Luh. "Selecting Input Factors for Clusters of Gaussian Radial Basis Function Networks to Improve Market Clearing Price Prediction." IEEE Transactions on Power Systems 18, no. 2 (May 2003): 665-72. doi:10.1109/TPWRS.2003.811012.

Kurniawan, Ardietya, and Muh Rosyid Ridlo. "Perilaku Konsumtif Remaja Penikmat Warung Kopi." DILEMA 32, no. 1 (April 29, 2017): 9-22. https://jurnal.uns.ac.id/dilema/article/vi ew/11232/pdf.

Mohiuddin, A. K. "Lifestyle Issues and Prevention of Recurrent UTIs." International Research in Medical and Health Science 2, no. 4 (September 4, 2019): $73-$ 82. doi:10.36437/irmhs.2019.2.4.S.

Rittiboonchai, Wisit, Penpicha Kriwuttisom, and Thi Minh Trang Ngo. "Factors Affecting Online Shopping Behavior Of Thaiand Vietnamese Female Students." RMUTT Global Business Accounting and Finance Review 2, no. 2 (January 4, 2019). http://www.journal.rmutt.ac.th/index.ph $\mathrm{p} / \mathrm{gbafr} /$ article/view/1240.

Saura, Jose Ramon, Pedro Palos-Sanchez, and Antonio Grilo. "Detecting Indicators for Startup Business Success: Sentiment Analysis Using Text Data Mining." Sustainability 11, no. 3 (February 11, 2019): 
917. doi:10.3390/su11030917.

Shan, Chenyu, Dragon Yongjun Tang, and Andrew Winton. "Do Banks Still Monitor When There Is a Market for Credit Protection?" Journal of Accounting and Economics 68, no. 2-3 (November 1, 2019): 101241. doi:10.1016/J.JACCECO.2019.101241.

Strumpel, Burkhard, Ed. "Economic Means for Human Needs: Social Indicators of WellBeing and Discontent." Survey Research Center, Institute for Social Research, University of Michigan, Ann Arbor, Michigan 48106 (\$14.00 clothbound), 1976.

https://eric.ed.gov/?id=ED129646.

Soekanto, Soerjono. 1990. Sosiologi suatu Pengantar. Jakarta: Raja Grafindo Persada. 